Supporting Information

\title{
Polyionic Nanoclays: Tailorable Hybrid Organic-Inorganic Catalytic Platforms
}

Nathaniel E. Larm, Laxmi Adhikari, Samantha McKee, and Gary A. Baker*

Department of Chemistry, University of Missouri, 601 S. College Avenue, Columbia, Missouri 65211, United States 


\section{Materials and Methods}

All experiments were carried out using ultrapure Millipore water $(18.2 \mathrm{M} \Omega \mathrm{cm})$. Reagents were purchased commercially and used without further purification. X-ray powder diffraction (XRPD) was performed using a Scintag X2 diffractometer with a monochromatic $\mathrm{Cu} \mathrm{k} \alpha(\lambda=1.5406 \AA)$ source operated at $45 \mathrm{kV}$ and 40 $\mathrm{mA}$ with a $2 \Theta$ angle pattern. Scanning was done in the region of $3^{\circ}-70^{\circ}$. Nuclear magnetic resonance (NMR) analysis was performed using either a Bruker Avance-500 MHz spectrometer or a Bruker Avance$600 \mathrm{MHz}$ spectrometer operated at 500 or $600 \mathrm{MHz}$, respectively (frequencies are appropriately denoted in the related figure captions). Transmission Fourier transform infrared (FTIR) spectroscopy was performed using a Nicolet Nexus 670 FTIR with potassium bromide (KBr) pellets, averaging 32 scans with a resolution of $2 \mathrm{~cm}^{-1}$. Thermogravimetric analysis (TGA) was performed using a TA Instruments Q50 TGA, with a Pt

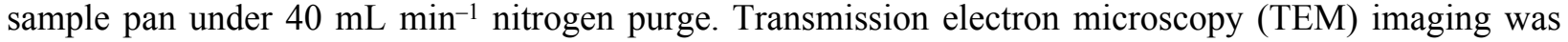
conducted on carbon-coated copper grids (Ted Pella, Inc. 01814-F, carbon type-B, 400 mesh copper grid) using a FEI Tecnai F20 microscope operating at a $200 \mathrm{keV}$ accelerating electron voltage. 300-400 individual AuNPs were analyzed for the generation of the particle size histograms. Scanning electron microscopy (SEM) imaging was conducted using a FEI Helios NanoLab 600 FIB/FESEM. Zeta potential measurements were performed in aqueous media using a Malvern Zetasizer Nano ZS in folded capillary zeta cells. An assumed refractive index of 1.6 (talc) was used for all calculations.

1-methylimidazole (M50834, 99\%), 1-butylimidazole (348414, 98\%), 1-bromooctane (152951, 99\%), imidazole (I202, 99\%), sodium hydride (223441, 95\%), magnesium chloride hexahydrate (M2670, $\geq 99.0 \%$ ), 3-chloropropyltrimethoxysilane (440183, $\geq 97 \%$ ), potassium bromide (P-5912, $\geq 99.0 \%$ ), deuterium oxide (151882; 99.9 atom\% D), sodium hydroxide (306576, 99.99\%), tetrachloroauric acid $(520918, \geq 99.9 \%$ ), and sodium borohydride $(213462,99 \%)$ were purchased from Sigma-Aldrich (St. Louis, MO). Ethyl acetate (E195-4, 99.9\%) was purchased from Fischer Scientific (Hampton, NH). (3iodopropyl)trimethoxysilane (SII6452.0) was purchased from Gelest (Morrisville, PA). Absolute ethanol (2716) was purchased from Decon Labs (King of Prussia, PA).

Characterization: NMR. ${ }^{1} \mathrm{H}$ nuclear magnetic resonance (NMR) spectra of each silane and PINC produced in this manuscript are presented. For brevity, peak assignments relating to the spectra in the manuscript (methylimidazolium iodide silane IL and PINC) are presented in the text here while those relating to spectra in this supporting document are presented in the text below their respective supporting figures.

The ${ }^{1} \mathrm{H}$ NMR spectrum for methylimidazolium iodide silane (Figure 1a) shows peaks for the residual solvent (chloroform) and water (at $2.1 \mathrm{ppm})$. The following shifts are identified (600 $\left.\mathrm{MHz} ; \mathrm{CDCl}_{3}\right): 9.93$ $(1 \mathrm{H}, \mathrm{s}, \mathrm{N}-\mathrm{CH}-\mathrm{N}), 7.58\left(1 \mathrm{H}, \mathrm{s}, \mathrm{CH}_{3}-\mathrm{N}-\mathrm{CH}-\mathrm{CH}\right), 7.43\left(1 \mathrm{H}, \mathrm{s}, \mathrm{CH}_{3}-\mathrm{N}-\mathrm{CH}-\mathrm{CH}\right), 4.29\left(2 \mathrm{H}, \mathrm{t}, \mathrm{N}-\mathrm{CH}_{2}\right), 4.07$ $\left(3 \mathrm{H}, \mathrm{s}, \mathrm{CH}_{3}-\mathrm{N}\right), 3.51\left(9 \mathrm{H}, \mathrm{s}, \mathrm{CH}_{3}-\mathrm{O}-\mathrm{Si}\right), 1.97\left(2 \mathrm{H}, \mathrm{m}, \mathrm{Si}_{-} \mathrm{CH}_{2}-\mathrm{CH}_{2}\right), 0.60\left(2 \mathrm{H}, \mathrm{t}, \mathrm{Si}-\mathrm{CH}_{2}\right)$.

The ${ }^{1} \mathrm{H}$ NMR spectrum for methylimidazolium iodide PINC (Figure 1b) shows the presence of residual solvent (ethanol) and reaction byproduct (methanol). The following shifts are identified $\left(500 \mathrm{MHz} ; \mathrm{D}_{2} \mathrm{O}\right)$ : $7.48\left(1 \mathrm{H}, \mathrm{s}, \mathrm{CH}_{3}-\mathrm{N}-\mathrm{CH}-\mathrm{CH}\right), 7.42\left(1 \mathrm{H}, \mathrm{s}, \mathrm{CH}_{3}-\mathrm{N}-\mathrm{CH}-\mathrm{CH}\right), 4.19\left(2 \mathrm{H}, \mathrm{t}, \mathrm{N}-\mathrm{CH}_{2}\right), 3.89\left(3 \mathrm{H}, \mathrm{s}, \mathrm{CH}_{3}-\mathrm{N}\right), 1.96$ $\left(2 \mathrm{H}, \mathrm{m}, \mathrm{Si}-\mathrm{CH}_{2}-\mathrm{CH}_{2}\right), 0.50\left(2 \mathrm{H}, \mathrm{t}, \mathrm{Si}-\mathrm{CH}_{2}\right)$. The proton located at the $\mathrm{N}-\mathrm{CH}-\mathrm{N}$ location experiences rapid exchange with $\mathrm{D}_{2} \mathrm{O}$, resulting in its absence in the spectrum.

The ${ }^{29} \mathrm{Si}$ NMR spectrum for [mpim]C1 PINC possesses T1, T2, and T3 peaks at $-50.7,-56.5$, and $-66.5 \mathrm{ppm}$, respectively.

Characterization: XRPD. It is known that during the formation of 2:1 phyllosilicate clays (such as talc), coordination of silanes around the octahedral $\mathrm{Mg}$ complex is limited by the hydrophobicity of the 
organosilane moieties, resulting in a lamellar structure, stacking of individual clay platelets, and characteristic reflections when analyzed using X-ray powder diffraction (XRPD). Therefore, analysis of the layered structure within the solid [mpim]I PINC was performed (Figure 1c), exhibiting reflections which are consistent with the parent Mg silicate (talc; JCPDS card 13-0558), albeit broader, with reflections at $3.93,2.47$, and $1.56 \AA$ corresponding to the clay $(020)(110),(130)(200)$, and (060)(330) reflections, respectively. These peak broadenings are attributed to interlayer disorder caused by the organic moieties present on the PINC surface, a feature which is consistent with the findings of Burkett et al. ${ }^{2}$ Furthermore, the $\mathrm{d}_{001}$ reflection, which is indicative of interlayer spacing, is not present when measured with a starting angle of $3^{\circ} 2 \Theta(29.43 \AA)$, indicating that the interlayer spacing has been increased by steric hindrance and, likely, repulsive surface charges as compared to the spacing and similar reflection in a smaller organic moiety, such as the propyl amine found on aminoclay. These results lend credence to the formation of a lamellar 2:1 phyllosilicate clay with a sterically hindered surface functionality. Comparatively, the butylimidazolium PINC exhibits all of the above reflections with the addition of a (001) reflection at $3.76^{\circ}$ $2 \Theta(23.48 \AA)$ and two sharp peaks (and an additional small peak) attributed to $\mathrm{NaCl}$ at $31.76^{\circ}$ and $45.50^{\circ}$ $2 \Theta$ (and $\sim 56.5^{\circ} 2 \Theta$ ).

Characterization: FTIR. Surface and framework vibrational modes within the alkylimidazolium PINC were analyzed using transmission Fourier transform infrared (FTIR) spectroscopy and were found to be consistent with those of a typical magneso-silicate structure, with absorption peaks observed at $\sim 515 \mathrm{~cm}^{-1}$ for $\mathrm{Mg}-\mathrm{O}, 1020 \mathrm{~cm}^{-1}$ for $\mathrm{Si}-\mathrm{O}-\mathrm{Si}, 1170 \mathrm{~cm}^{-1}$ for $\mathrm{Si}-\mathrm{C}, 3450 \mathrm{~cm}^{-1}$ for $\mathrm{O}-\mathrm{H}$, and $3700 \mathrm{~cm}^{-1}$ for $\mathrm{MgO}-\mathrm{H}$. Furthermore, the organic moieties within IL portion of the alkylimidazolium halide PINCs displayed characteristic peaks resembling those of similar ILs ${ }^{3}$ at $1380-1480 \mathrm{~cm}^{-1}$ for $\mathrm{C}-\mathrm{N}, 1572 \mathrm{~cm}^{-1}$ for $\mathrm{C}-\mathrm{C}, 2937$ $\mathrm{cm}^{-1}$ for alkyl $\mathrm{C}-\mathrm{H}$, and $3000-3150 \mathrm{~cm}^{-1}$ for ring $\mathrm{C}-\mathrm{H}$. Further, the anion exchange precipitate proposed to be $[$ mpim] $]$ Tf2N] PINC showed peaks belonging to both the cation moiety and the $\mathrm{Tf}_{2} \mathrm{~N}^{-}$anion, indicating that metathesis did indeed occur.

Characterization: TGA. Thermogravimetric analysis (TGA) was performed $\left(10{ }^{\circ} \mathrm{C} \mathrm{min}{ }^{-1}\right.$ from RT to 600 ${ }^{\circ} \mathrm{C} ; 40 \mathrm{~mL} \mathrm{~min}^{-1} \mathrm{~N}_{2}$ gas flow) to determine the degradation temperatures of the organic moieties in our PINC composites. For [mpim] I PINC (Figure 1e), an approximate $9 \%$ mass loss while heating to $200{ }^{\circ} \mathrm{C}$ is attributed to gradual release and evaporation of water, $\mathrm{EtOH}$, and $\mathrm{MeOH}$ trapped within the interlayer structure of the foliated PINCs. Degradation of the methylimidazolium functionality occurs between 250 ${ }^{\circ} \mathrm{C}$ and $450{ }^{\circ} \mathrm{C}$, and accounts for approximately $31 \%$ of the overall sample mass, followed by degradation of the propyl chain ( $\sim 8 \%$ mass loss) from $475{ }^{\circ} \mathrm{C}$ to $600{ }^{\circ} \mathrm{C}$. The remaining material, accounting for $\sim 52 \%$ of the original mass, consists of the $\mathrm{Mg}$ silicate backbone and residual char. The [bpim]I PINC exhibited similar thermogravimetric degradation, with an approximate $6 \%$ mass loss before $200{ }^{\circ} \mathrm{C}$ attributed to gradual release and evaporation of water, $\mathrm{EtOH}$, and $\mathrm{MeOH}, 30 \%$ mass loss from 225 to $375^{\circ} \mathrm{C}$ attributed to degradation of the butylimidazolium functionality, and $20 \%$ mass loss from 375 to $600{ }^{\circ} \mathrm{C}$ attributed to degradation of the propyl chain. For [opim]I PINC, $7 \%$ mass loss before $200{ }^{\circ} \mathrm{C}$ is attributed to gradual release and evaporation of water, $\mathrm{EtOH}$, and $\mathrm{MeOH}$ while $21 \%$ mass loss from 250 to $450{ }^{\circ} \mathrm{C}$ is attributed to degradation of the octylimidazolium functionality and $10 \%$ mass loss from 475 to $600{ }^{\circ} \mathrm{C}$ is attributed to degradation of the propyl chain. Note that the disproportionate mass losses observed for the organic components in [opim] I PINC are tentatively attributed to residual $\mathrm{NaCl}$ (presence evident in XRPD, Figure S5).

4-nitrophenol catalysis calculations. The linear correlation of $\ln \left(A_{0} / A_{\mathrm{t}}\right)$ vs. time was used to calculate the apparent rate constants $\left(k_{\text {app }}\right)$ for 4-NP reduction, while the moles of 4-NP $\left(n_{4-\mathrm{NP}}\right)$ divided by the product of moles of $\mathrm{Au}\left(n_{\mathrm{Au}}\right)$ and reaction time $\left(t_{\mathrm{rxn}}\right)$ were used to calculate the turnover frequency (TOF), corrected for the reaction completion, as shown in equation $\mathrm{S} 1$. Note that reaction time is defined here as the time 
from reaction initiation to the time when the value for $\ln \left(A_{0} / A_{\mathrm{t}}\right)$ equals 3 , and that the reaction completion percentage at $\ln \left(A_{0} / A_{\mathrm{t}}\right)$ equals 3 is $95 \%$.

$$
\text { TOF }=\frac{n_{4-\mathrm{NP}}}{\left(n_{\mathrm{m}}\right)\left(t_{\mathrm{rxn}}\right)} \times \frac{\text { completion } \%}{100}
$$

Similar reductions were performed using 2-month-old PINC@AuNPs, with little change in the catalytic activity. Further, a 10-day-old stock and a 2-month-old stock were separately used to test the recyclability of these PINC@AuNPs as catalysts. As above, $2.10 \mathrm{~mL}$ of $0.20 \mathrm{mM}$ aqueous 4-NP and $0.90 \mathrm{~mL}$ of freshly prepared $100 \mathrm{mM}$ aqueous $\mathrm{NaBH}_{4}$ were mixed in a 4-mL PMMA cuvette, followed by addition of $2.1 \mu \mathrm{L}$ of $1.0 \mathrm{mM}$ PINC@AuNPs (representing $0.5 \mathrm{~mol} \%$ Au with respect to 4-NP). The sample was mixed via inversion and the reduction was monitored at $400 \mathrm{~nm}$ using UV-vis spectroscopy. Once the absorbance reached $\geq 95 \%$ completion, $84 \mu \mathrm{L}$ of $5.0 \mathrm{mM} 4$-NP was rapidly added and the solution was quickly mixed with inversion and replaced in the instrument. Due to the slight dilution and the reaction progress during mixing, these spectra begin at absorbances below the initial absorbance, which lends some error to the catalytic rate assessment. Three such reduction cycles proceeded without a noticeable decrease in catalytic rate, with the fourth and fifth cycles possessing significantly retarded rates. Therefore, $90 \mu \mathrm{L}$ of $1.0 \mathrm{M}$ $\mathrm{NaBH}_{4}$ was added in addition to the 4-NP for the sixth and seventh cycles, resulting in a return of the catalyzed rate to almost the initial values. This implies that the PINC@AuNPs can be recycled at least seven times for this reaction.

Table S1. Examples of 4-NP catalysts from the literature.

\begin{tabular}{|c|c|c|c|c|c|c|c|}
\hline catalyst & stabilizer & shape & $\begin{array}{l}\text { size } \\
(\mathrm{nm})\end{array}$ & $\begin{array}{l}\text { metal } \\
(\% \mathrm{~mol})\end{array}$ & $k_{\mathrm{app}}\left(\mathrm{s}^{-1}\right)$ & TOF $\left(h^{-1}\right)$ & Ref. \\
\hline AuNPs & boron nitride & spherical & 8.2 & 635 & 0.000833 & 0.00158 & 5 \\
\hline AuNPs & Breynia rhamnoides & spherical & 25 & 30 & 0.00766 & 0.175 & 6 \\
\hline AuNPs & chitosan & spherical & $20-24$ & 31.7 & 0.0561 & 212 & 7 \\
\hline AuNPs & cellulose nanofibers & spherical & 5 & 0.67 & 0.0059 & 563 & 8 \\
\hline AuNPs & Cylindrocladium floridanum & spherical & 25 & 5 & 0.0267 & 641 & 9 \\
\hline AuNPs & poly(ethylenimine) & spherical & $4-13$ & 0.68 & 0.0070 & 1,200 & 10 \\
\hline $\mathrm{Au}_{0.7} \mathrm{Ag}_{0.3} \mathrm{NPs}$ & {$\left[\text { closo }-\mathrm{B}_{10} \mathrm{H}_{10}\right]^{2-}$} & spherical & 4.2 & 5 & 0.200 & 4,672 & 11 \\
\hline AuNPs & borohydride & spherical & 3 & 0.2 & 0.009 & 9,000 & 12 \\
\hline AuNPs & [mpim]Cl PINC & spherical & 2.5 & 0.1 & 0.0358 & 25,000 & $\begin{array}{l}\text { this } \\
\text { work }\end{array}$ \\
\hline
\end{tabular}



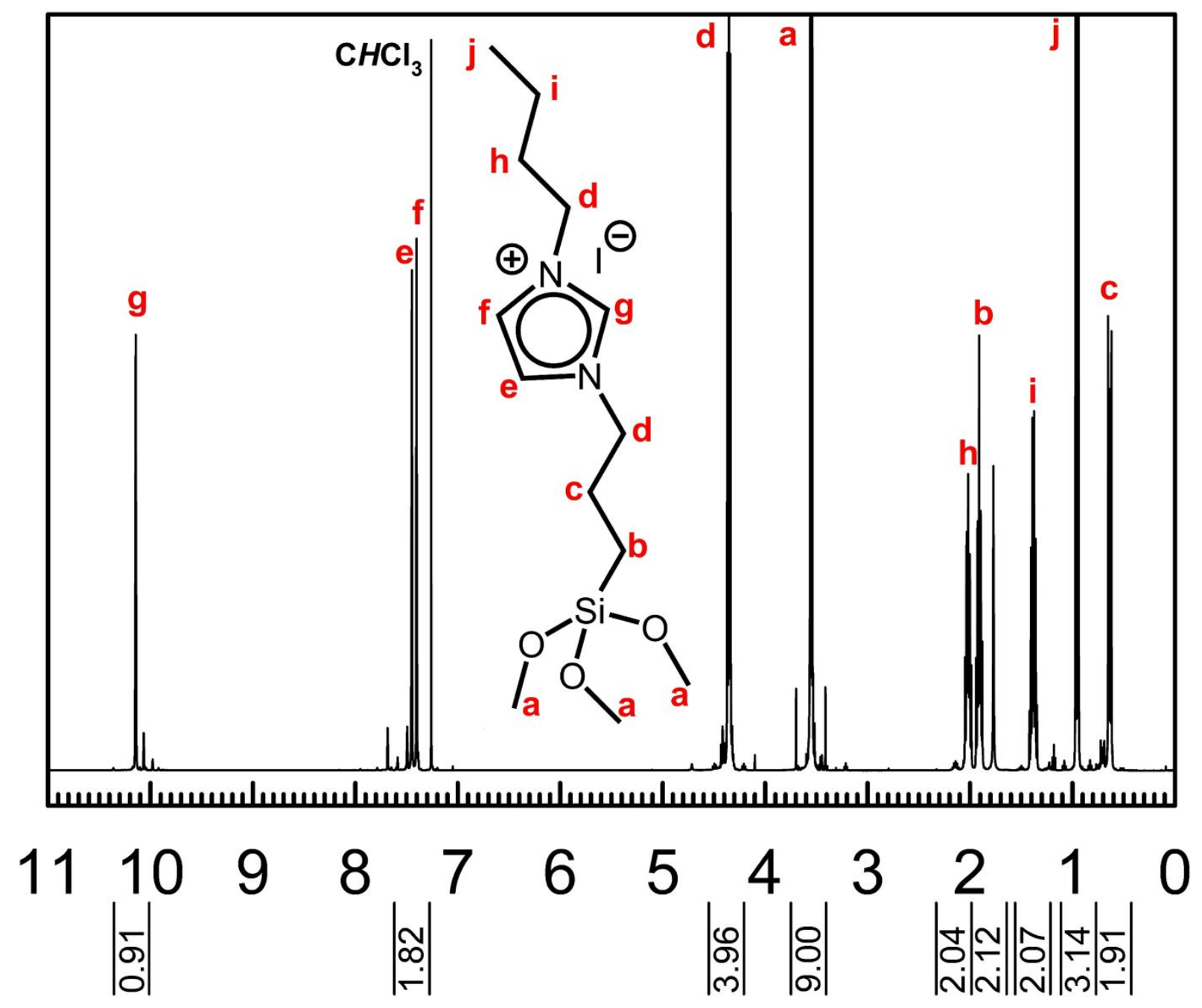

Figure S1. ${ }^{1} \mathrm{H}-\mathrm{NMR}$ spectrum of butylimidazolium iodide silane IL. Peak assignments show the presence of residual solvent (chloroform) and possibly water (at $1.8 \mathrm{ppm}$ ). The following shifts are identified $\left(500 \mathrm{MHz} ; \mathrm{CDCl}_{3}\right): 10.18(1 \mathrm{H}, \mathrm{s}, \mathrm{N}-\mathrm{CH}-\mathrm{N}), 7.45$ and $7.40\left(1 \mathrm{H}\right.$ each, s, $\left.\mathrm{CH}_{2}-\mathrm{N}-\mathrm{CH}-\mathrm{CH}\right), 4.35\left(4 \mathrm{H}, \mathrm{t}, \mathrm{CH}_{2}-\right.$ $\left.\mathrm{N}-\mathrm{CH}-\mathrm{N}-\mathrm{CH}_{2}\right), 3.56\left(9 \mathrm{H}, \mathrm{s}, \mathrm{CH}_{3}-\mathrm{O}-\mathrm{Si}\right), 2.03\left(2 \mathrm{H}, \mathrm{m}, \mathrm{CH}_{3}-\mathrm{CH}_{2}-\mathrm{CH}_{2}\right), 1.91\left(2 \mathrm{H}, \mathrm{m}, \mathrm{Si}-\mathrm{CH}_{2}\right), 1.39(2 \mathrm{H}, \mathrm{m}$, $\left.\mathrm{CH}_{3}-\mathrm{CH}_{2}\right), 0.96\left(3 \mathrm{H}, \mathrm{t}, \mathrm{CH}_{3}\right), 0.64\left(2 \mathrm{H}, \mathrm{t}, \mathrm{Si}-\mathrm{CH}_{2}-\mathrm{CH}_{2}\right)$. 


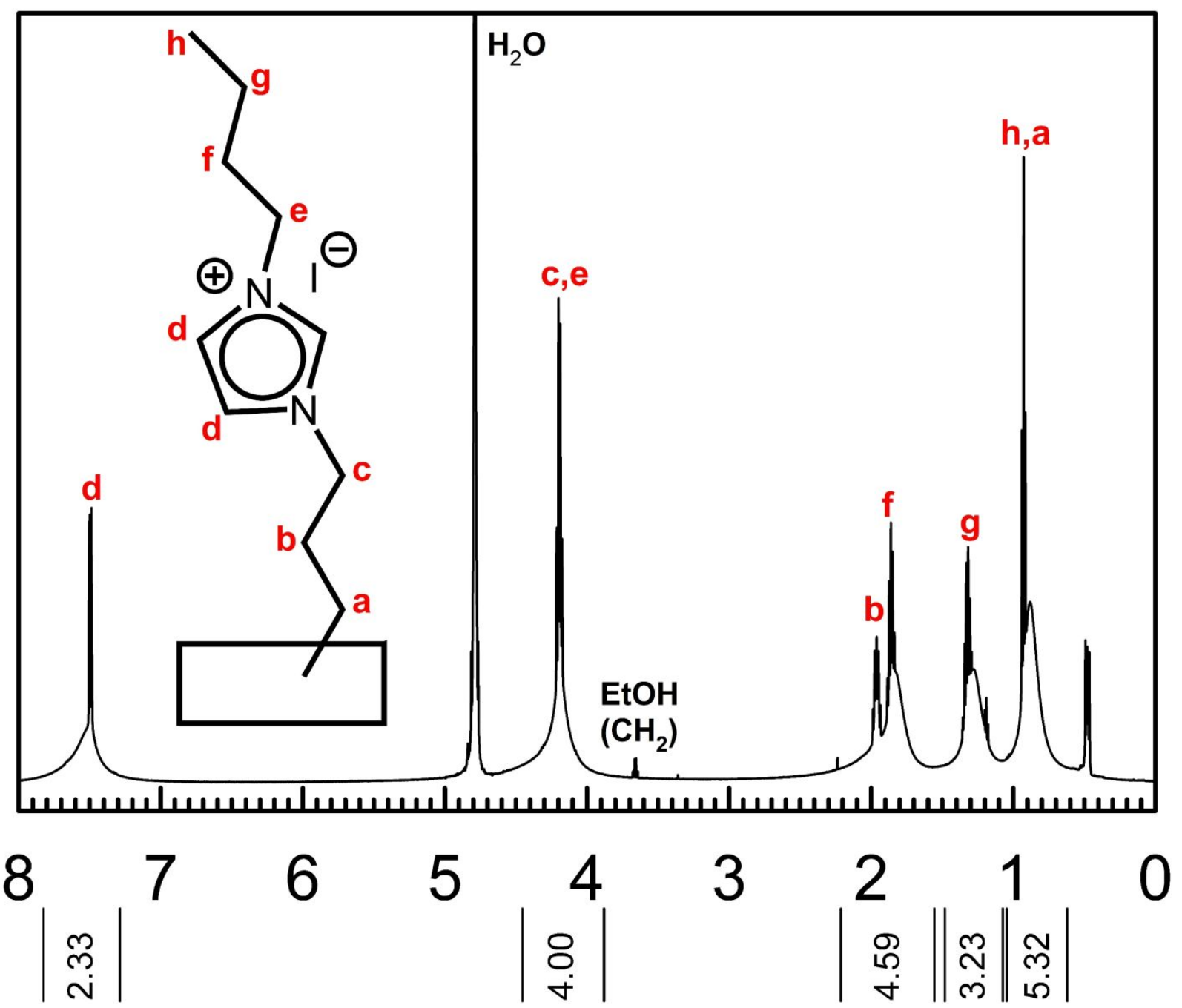

Figure S2. ${ }^{1} \mathrm{H}-\mathrm{NMR}$ spectrum of the butylimidazolium iodide PINC. Interlocking of the longer alkyl chain branching from the imidazolium ring disuades delamination of the PINC in water, resulting in broader peaks than those observed in the methylimidazolium iodide PINC. This broadening also reduces peak resolution, producing a significant hurdle for integration. Peak assignments show the presence of residual solvent (ethanol). The following shifts are identified $\left(600 \mathrm{MHz} ; \mathrm{D}_{2} \mathrm{O}\right): 7.49\left(2 \mathrm{H}, \mathrm{s}, \mathrm{CH}_{2}-\mathrm{N}-\mathrm{CH}-\mathrm{CH}\right), 4.19$ $\left(4 \mathrm{H}, \mathrm{m}, \mathrm{CH}_{2}-\mathrm{N}-\mathrm{CH}-\mathrm{N}-\mathrm{CH}_{2}\right), 1.96\left(2 \mathrm{H}, \mathrm{m}, \mathrm{Si}-\mathrm{CH}_{2}-\mathrm{CH}_{2}\right), 1.87\left(2 \mathrm{H}, \mathrm{m}, \mathrm{CH}_{3}-\mathrm{CH}_{2}-\mathrm{CH}_{2}\right), 1.33\left(3 \mathrm{H}, \mathrm{m}, \mathrm{CH}_{3}-\right.$ $\left.\mathrm{CH}_{2}\right), 0.94\left(3 \mathrm{H}, \mathrm{s}, \mathrm{CH}_{3}\right), 0.93\left(2 \mathrm{H}, \mathrm{s}\right.$, clay- $\left.\mathrm{CH}_{2}\right)$. The proton located at the $\mathrm{N}-\mathrm{CH}-\mathrm{N}$ location experiences rapid exchange with $\mathrm{D}_{2} \mathrm{O}$, resulting in its absence from the spectrum. 


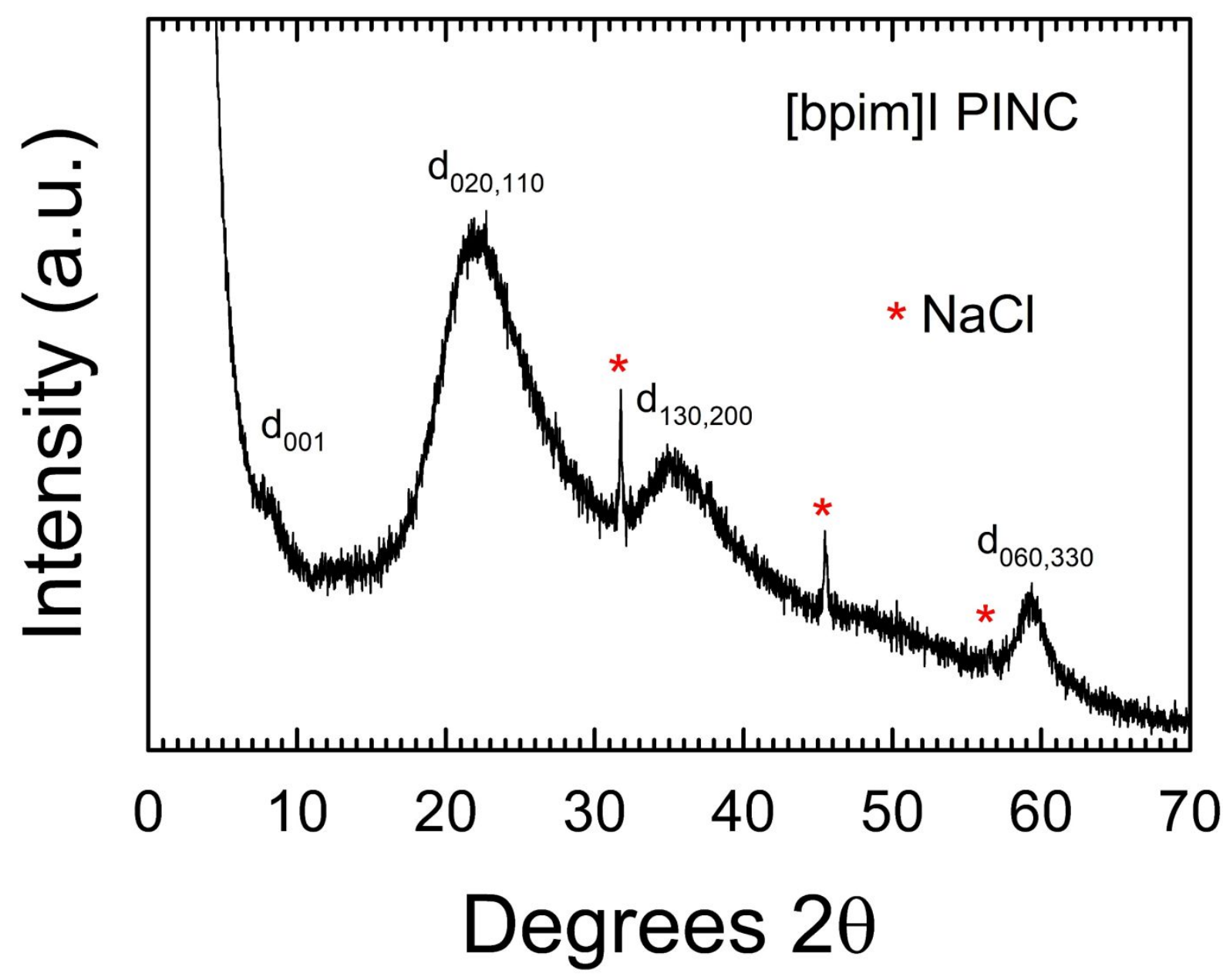

Figure S3. XRPD diffractogram for the butylimidazolium iodide PINC. Sharp peaks are present at $32^{\circ}$, $45^{\circ}$, and $57^{\circ} 2 \Theta$, corresponding to the (200), (220), and (222) reflections in NaCl, respectively. All other reflections are indicative of a 2:1 phyllosilicate clay, with peak broadening attributed to the large organic moiety [(1-butyl-(3-propyl)imidazolium] present on the lamella surface 

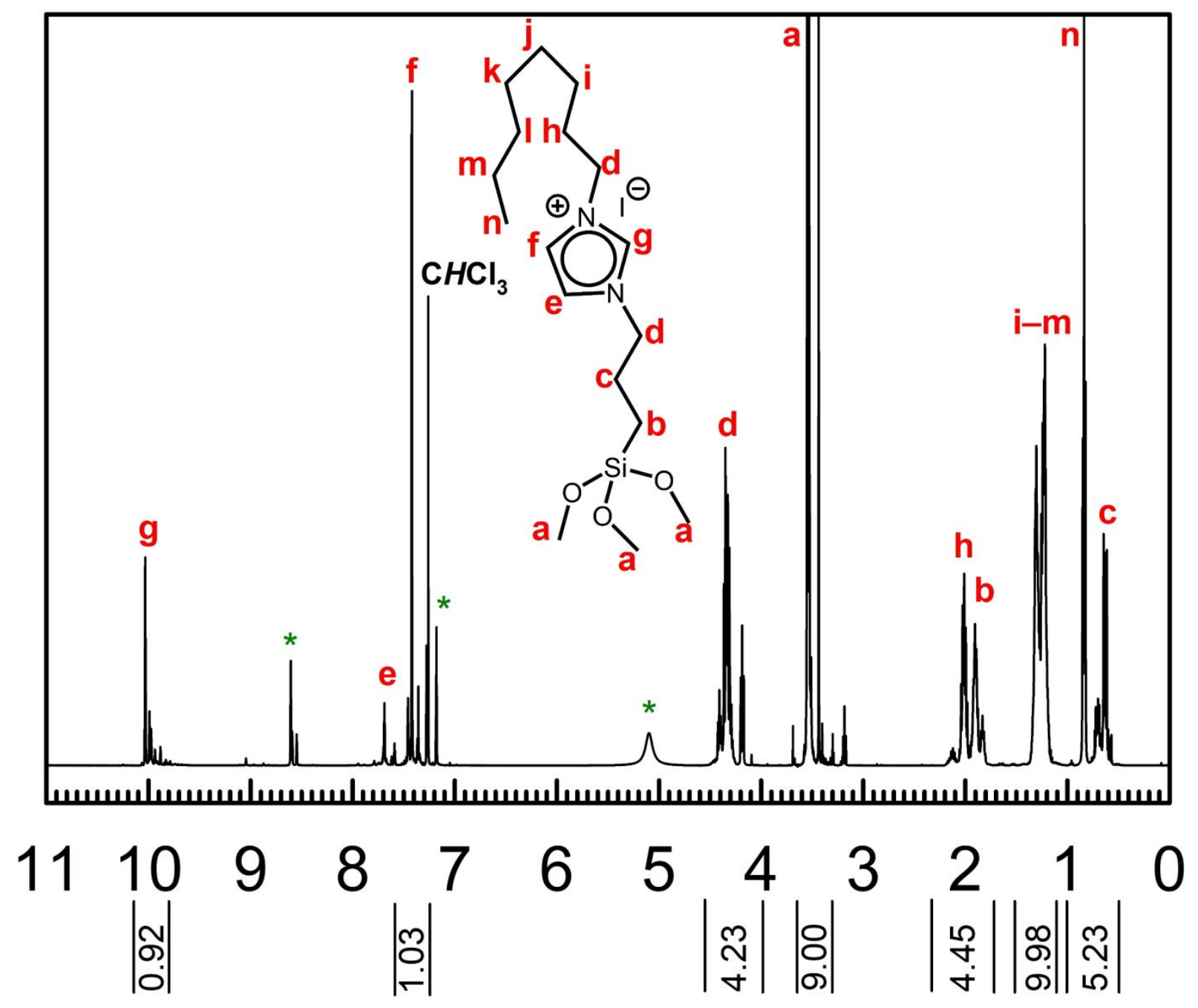

Figure S4. ${ }^{1} \mathrm{H}-\mathrm{NMR}$ spectrum of octylimidazolium iodide silane IL. Peak assignments show the presence of residual solvent (chloroform) and possibly water (at $1.8 \mathrm{ppm})$. The following shifts are identified (500 $\left.\mathrm{MHz} ; \mathrm{CDCl}_{3}\right): 10.03(1 \mathrm{H}, \mathrm{s}, \mathrm{N}-\mathrm{CH}-\mathrm{N}), 7.69$ and $7.42\left(1 \mathrm{H}\right.$ each, s, $\left.\mathrm{CH}_{2}-\mathrm{N}-\mathrm{CH}-\mathrm{CH}\right), 4.34\left(4 \mathrm{H}, \mathrm{m}, \mathrm{CH}_{2}-\mathrm{N}-\right.$ $\left.\mathrm{CH}-\mathrm{N}-\mathrm{CH}_{2}\right), 3.54\left(9 \mathrm{H}, \mathrm{s}, \mathrm{CH} \mathrm{H}_{3} \mathrm{-O}-\mathrm{Si}\right), 2.01\left(2 \mathrm{H}, \mathrm{m}, \mathrm{Si}-\ldots-\mathrm{N}_{-} \mathrm{CH}_{2}-\mathrm{CH}_{2}\right), 1.90\left(2 \mathrm{H}, \mathrm{m}, \mathrm{Si}-\mathrm{CH}_{2}\right), 1.26(10 \mathrm{H}$, m, $\left.\mathrm{CH}_{3}-\mathrm{CH}_{2}-\mathrm{CH}_{2}-\mathrm{CH}_{2}-\mathrm{CH}_{2}-\mathrm{CH}_{2}\right), 0.84\left(3 \mathrm{H}, \mathrm{t}, \mathrm{CH}_{3}\right), 0.63\left(2 \mathrm{H}, \mathrm{t}, \mathrm{Si}-\mathrm{CH}_{2}-\mathrm{CH}_{2}\right)$. Peaks marked with a green asterisk (*) are unidentified but may belong to a degradant of octyimidazole. 


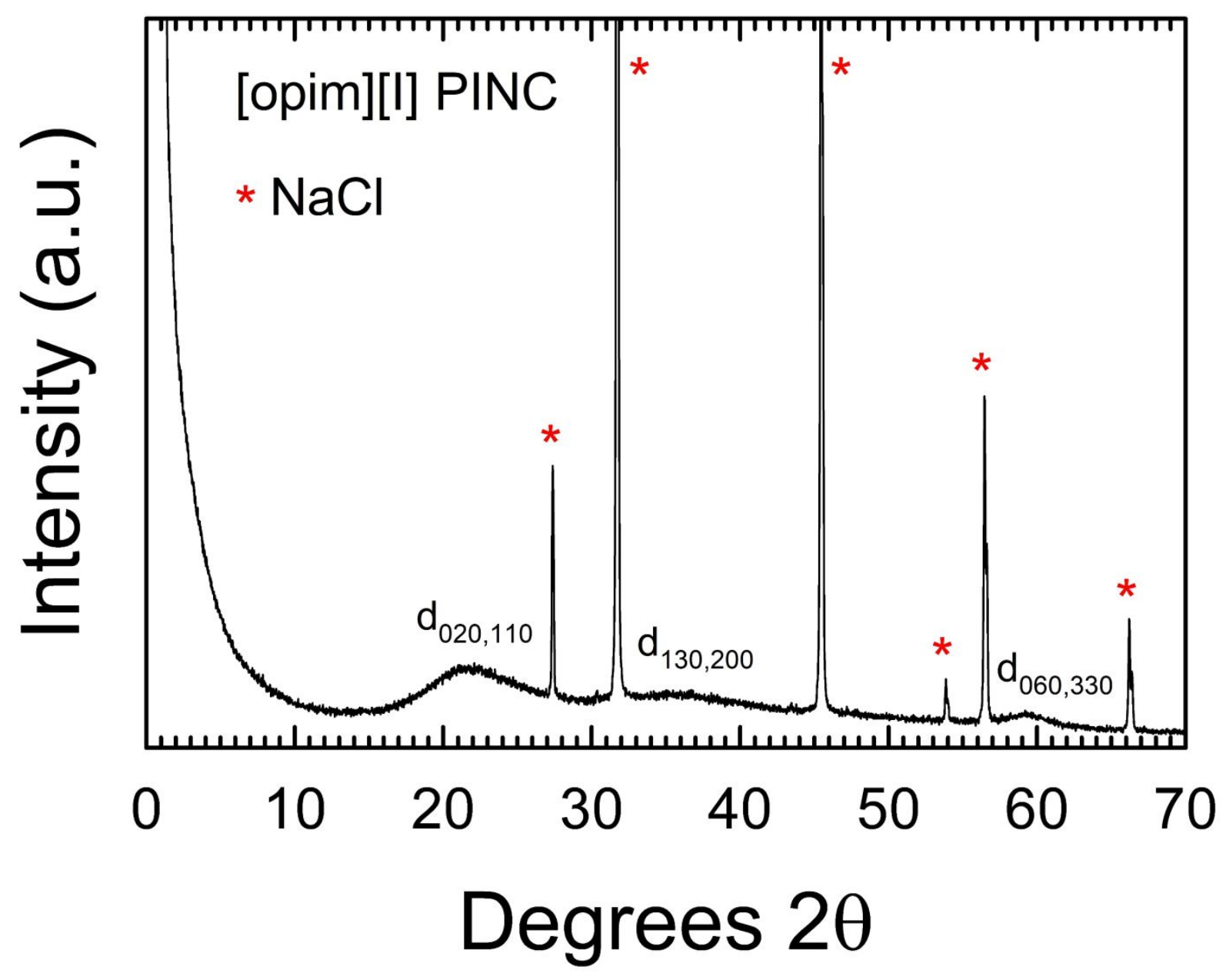

Figure S5. XRPD diffractogram for the octylimidazolium iodide PINC. Sharp peaks are present at $27^{\circ}$, $32^{\circ}, 45^{\circ}, 54^{\circ}, 57^{\circ}$, and $66^{\circ} 2 \Theta$, corresponding to the (111), (200), (220), (311), (222), and (400) reflections in $\mathrm{NaCl}$, respectively. All other reflections are indicative of a 2:1 phyllosilicate clay, with peak broadening attributed to the large organic moiety [(1-octyl-(3-propyl)imidazolium] present on the lamella surface. It is possible that the absence of the (001) reflection in the PINC, typically found near $8^{\circ} 2 \Theta$, is indicative of a large interlayer spacing in the lamellar structure resulting from steric hinderances caused by the large octyl chain. 


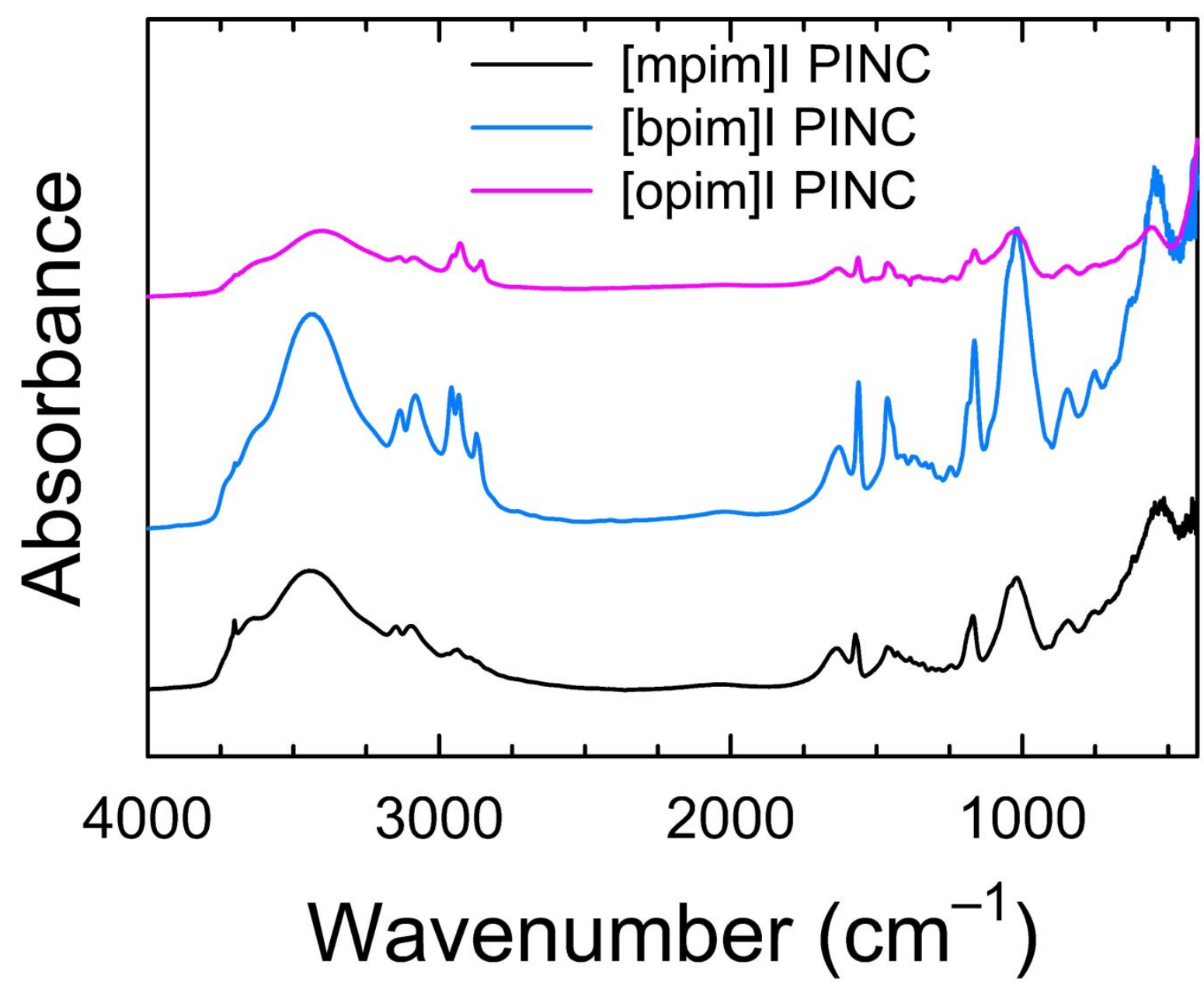

Figure S6. Transmission FTIR spectra of the [m-, [b, and [opim]I PINCs. Magneso-silicate peaks are observed at $\sim 520 \mathrm{~cm}^{-1}$ for $\mathrm{Mg}-\mathrm{O}, 1015-1020 \mathrm{~cm}^{-1}$ for $\mathrm{Si}-\mathrm{O}-\mathrm{Si}, 1165-1170 \mathrm{~cm}^{-1}$ for $\mathrm{Si}-\mathrm{C}, 3430-3450 \mathrm{~cm}^{-}$ ${ }^{1}$ for $\mathrm{O}-\mathrm{H}$, and $3700 \mathrm{~cm}^{-1}$ for $\mathrm{MgO}-\mathrm{H}$. Organic moieties display characteristic peaks at $1380-1480 \mathrm{~cm}^{-1}$ for $\mathrm{C}-\mathrm{N}, 1560-1575 \mathrm{~cm}^{-1}$ for $\mathrm{C}-\mathrm{C}, 2930-2960 \mathrm{~cm}^{-1}$ for alkyl C-H, and $3000-3150 \mathrm{~cm}^{-1}$ for ring $\mathrm{C}-\mathrm{H}$. 


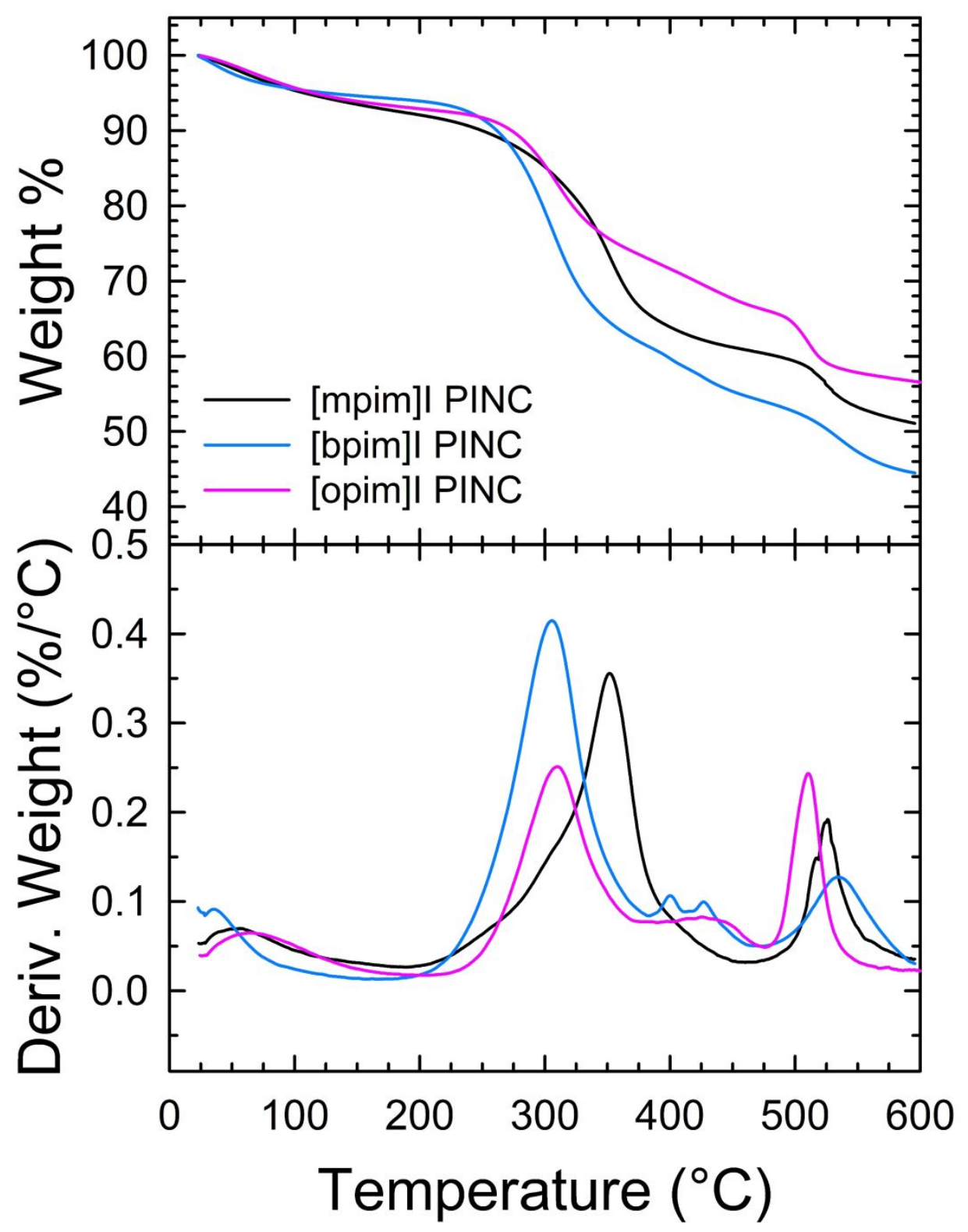

Figure S7. TGA thermogram (top) and $1^{\text {st }}$ derivative plot (bottom) for the methylimidazolium and butylimidazolium iodide PINCs. For [mpim]I PINC, the following mass losses are noted: $9 \%$ loss before $200{ }^{\circ} \mathrm{C}$ attributed to gradual release and evaporation of water, $\mathrm{EtOH}$, and $\mathrm{MeOH} ; 31 \%$ mass loss from 250 to $450{ }^{\circ} \mathrm{C}$ attributed to degradation of the methylimidazolium functionality; $8 \%$ mass loss from 475 to 600 ${ }^{\circ} \mathrm{C}$ attributed to degradation of the propyl chain. For the [bpim]I PINC, the following mass losses are noted: $6 \%$ loss before $200{ }^{\circ} \mathrm{C}$ attributed to gradual release and evaporation of water, $\mathrm{EtOH}$, and $\mathrm{MeOH} ; 30 \%$ mass loss from 225 to $375{ }^{\circ} \mathrm{C}$ attributed to degradation of the butylimidazolium functionality; $20 \%$ mass loss from 375 to $600{ }^{\circ} \mathrm{C}$ attributed to degradation of the propyl chain. For [opim]I PINC, the following mass losses are noted: $7 \%$ loss before $200{ }^{\circ} \mathrm{C}$ attributed to gradual release and evaporation of water, EtOH, and $\mathrm{MeOH} ; 21 \%$ mass loss from 250 to $450{ }^{\circ} \mathrm{C}$ attributed to degradation of the octylimidazolium functionality; $10 \%$ mass loss from 475 to $600{ }^{\circ} \mathrm{C}$ attributed to degradation of the propyl chain. Note that the disproportionate mass losses observed for the organic components in [opim]I PINC are tentatively attributed to residual $\mathrm{NaCl}$ (presence evident in XRPD). 


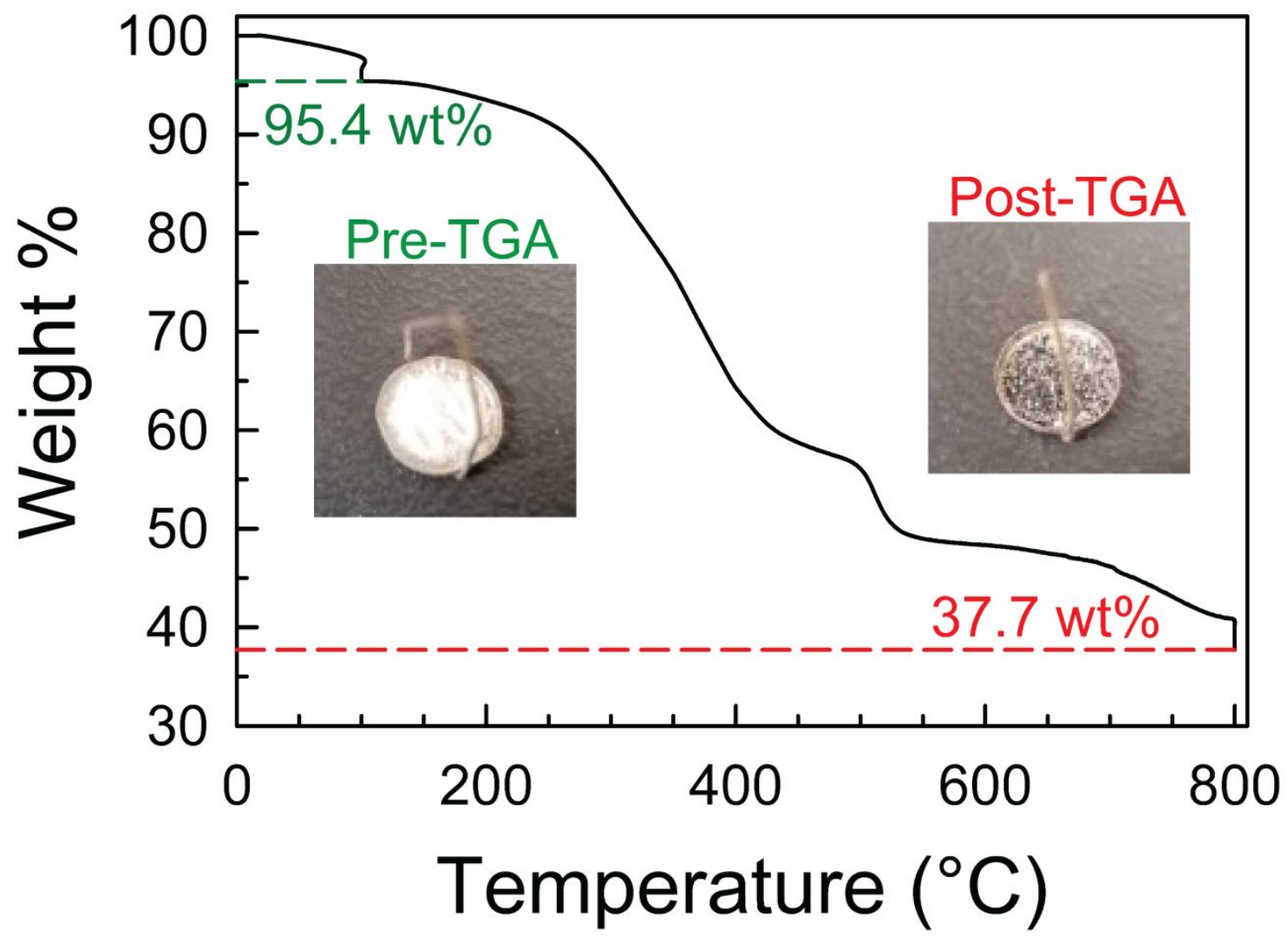

Figure S8. A TGA profile for [mpim]C1 PINC which was, prior to analysis, cleaned repeatedly with ethanol and thoroughly dried to remove as much solvent and interlamellar salt and reactants as possible. Using a heating rate of $10{ }^{\circ} \mathrm{C} \mathrm{min}-1$, the white sample was heated from room temperature to $100{ }^{\circ} \mathrm{C}$, where it remained for $1 \mathrm{~h}$, and then continued to $800^{\circ} \mathrm{C}$, where it remained for $1 \mathrm{~h}$. Subtracting the $\mathrm{wt} \%$ after drying at $100{ }^{\circ} \mathrm{C}$ for $1 \mathrm{~h}(95.4 \mathrm{wt} \%)$ and after run completion $(37.7 \mathrm{wt} \%)$ yields a total mass loss due to degradation of organic moieties (i.e., the covalently-bound IL) of $57.7 \mathrm{wt} \%$. Using the molecular weight of the [mpim]Cl IL moiety (159.64 $\left.\mathrm{g} \mathrm{mol}^{-1}\right)$, we calculate an IL loading of $3.8 \mathrm{mmol} \mathrm{g}^{-1}$. We note that the presence of residual salt and char, the latter of which can be seen in the "post-TGA" picture, can cause error in this estimation. 

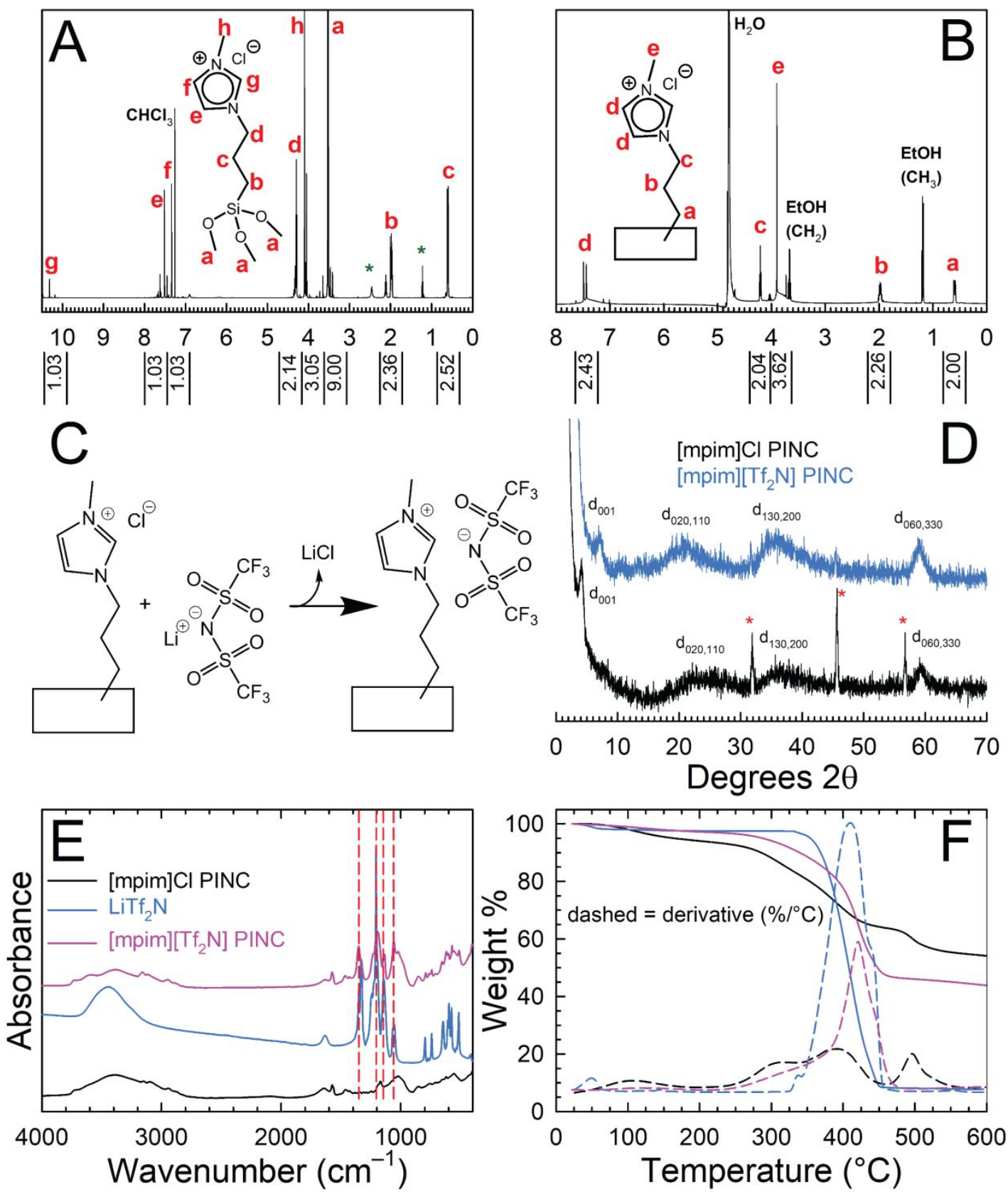

Figure S9. Characterization of [mpim]Cl silane IL/PINC and [mpim] $\left.] \mathrm{Tf}_{2} \mathrm{~N}\right]$ PINC. A) and B) [mpim]Cl silane IL and PINC ${ }^{1} \mathrm{H}-\mathrm{NMR}$ spectra. Green asterisks $(*)$ denote impurities tentatively attributed to degraded methyl imidazole. C) Scheme showing the anion exchange between [mpim]Cl PINC and [mpim] $\left[\mathrm{Tf}_{2} \mathrm{~N}\right]$. D) PXRD diffractograms for both [mpim] Cl and [mpim][Tf $\left.{ }_{2} \mathrm{~N}\right]$ PINCs, with red asterisks (*) denoting the $\mathrm{NaCl}$ (200), (220), and (222) impurity peaks. The higher diffraction angle for the (001) peak in $[\mathrm{mpim}]\left[\mathrm{Tf}_{2} \mathrm{~N}\right] \mathrm{PINC}$ when compared to $[\mathrm{mpim}] \mathrm{Cl} \mathrm{PINC}$ is attributed to the hydration of $\mathrm{Cl}^{-}$, which expands the interlayer region. E) FTIR spectra, with the denoted $v_{\mathrm{a}} \mathrm{S}=\mathrm{O}\left(1350 \mathrm{~cm}^{-1}\right), v_{\mathrm{a}} \mathrm{C}-\mathrm{F}$ (peak at 1147 $\mathrm{cm}^{-1}$ and shoulder at $\left.1230 \mathrm{~cm}^{-1}\right)$, and $v_{\mathrm{a}} \mathrm{S}-\mathrm{N}-\mathrm{S}\left(1060 \mathrm{~cm}^{-1}\right)$ bands arising from the $\left[\mathrm{Tf}_{2} \mathrm{~N}\right]^{-}$anion. F) TGA thermogram (solid lines) and first derivative plot (dashed lines) for each analyte from panel E, with characteristic mass losses from $\mathrm{Tf}_{2} \mathrm{~N}^{-}$in the corresponding [mpim] $\left[\mathrm{Tf}_{2} \mathrm{~N}\right] \mathrm{PINC}$. The legend in panel $\mathrm{E}$ also applies to panel F. 


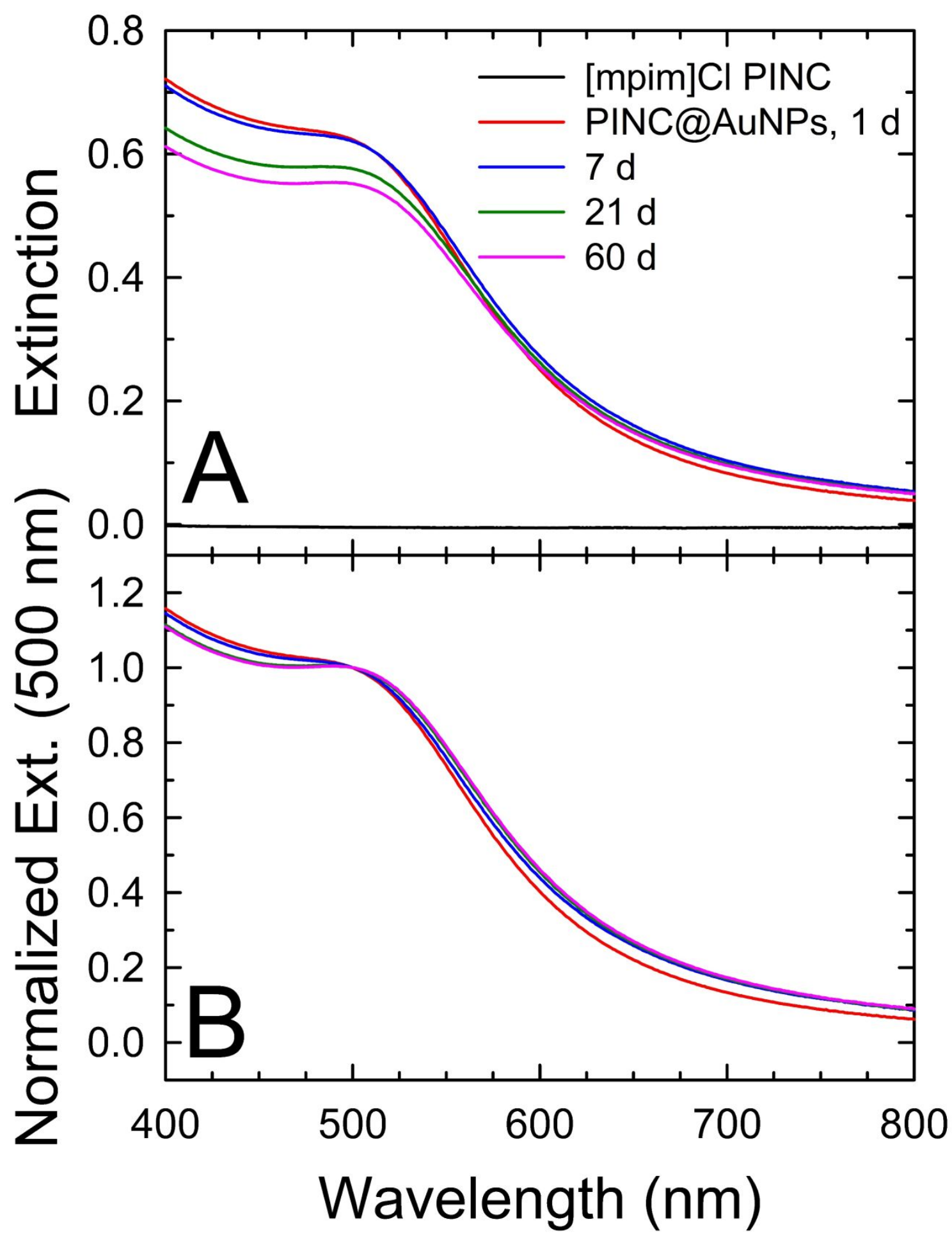

Figure S10. Stability analysis showing A) the UV-vis spectra showing PINC@AuNP (1.0 mM Au sample, diluted to $0.25 \mathrm{mM}$ for measurement) stability and B) the corresponding normalized spectra. A very slight red shift $(\sim 2 \mathrm{~nm})$ was observed in the spectra for samples aged for 21 and $60 \mathrm{~d}$, indicating slight growth in the AuNPs over time. 

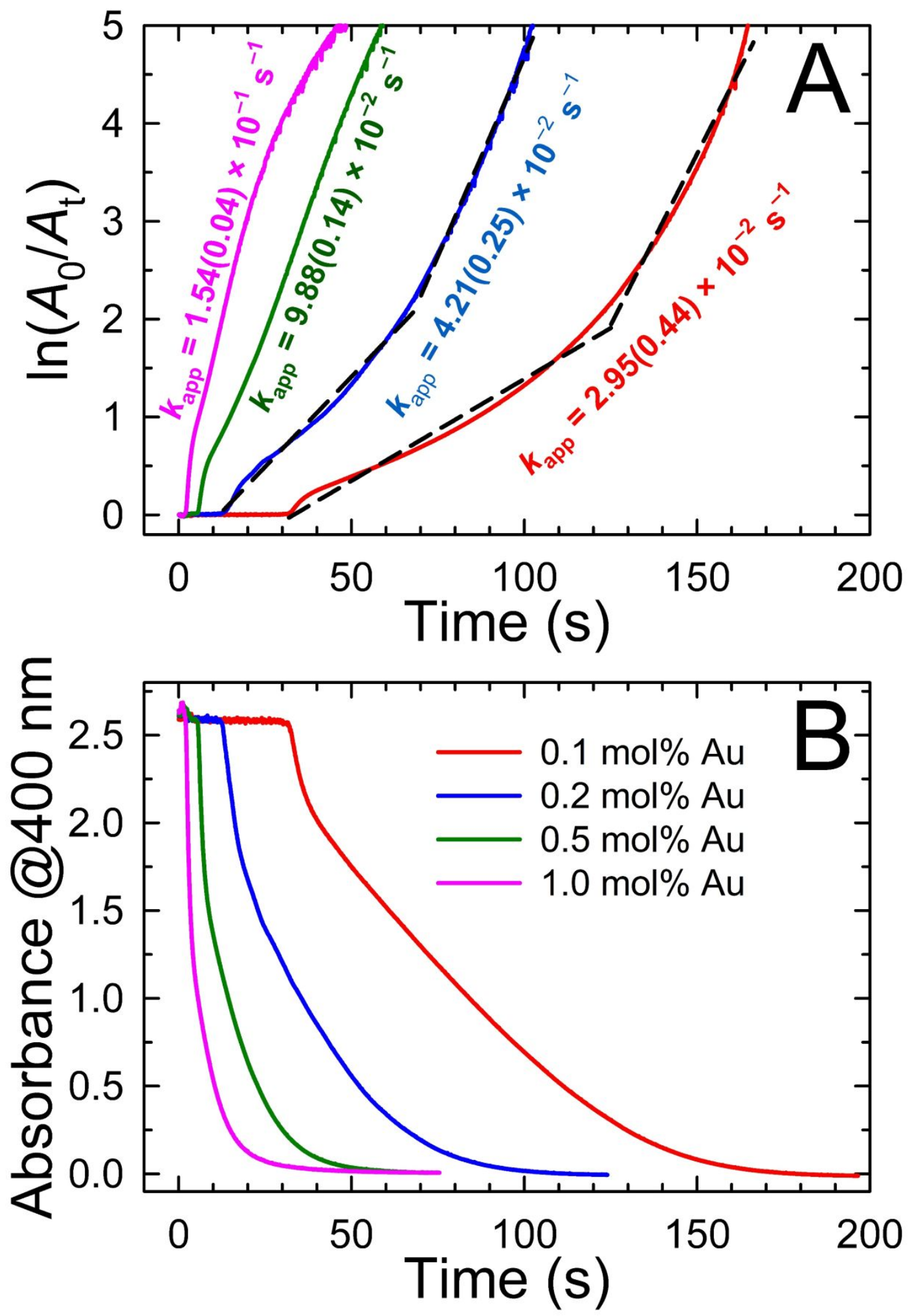

Figure 11. A) Rate plot and B) spectra showing the reduction of 4-NP to 4-AP using $\mathrm{NaBH}_{4}$ and 2-monthold PINC@AuNPs as the catalyst. The apparent rates indicated in A) show good agreement with those obtained from 1-day-old PINC@AuNPs, indicating good catalyst stability. 


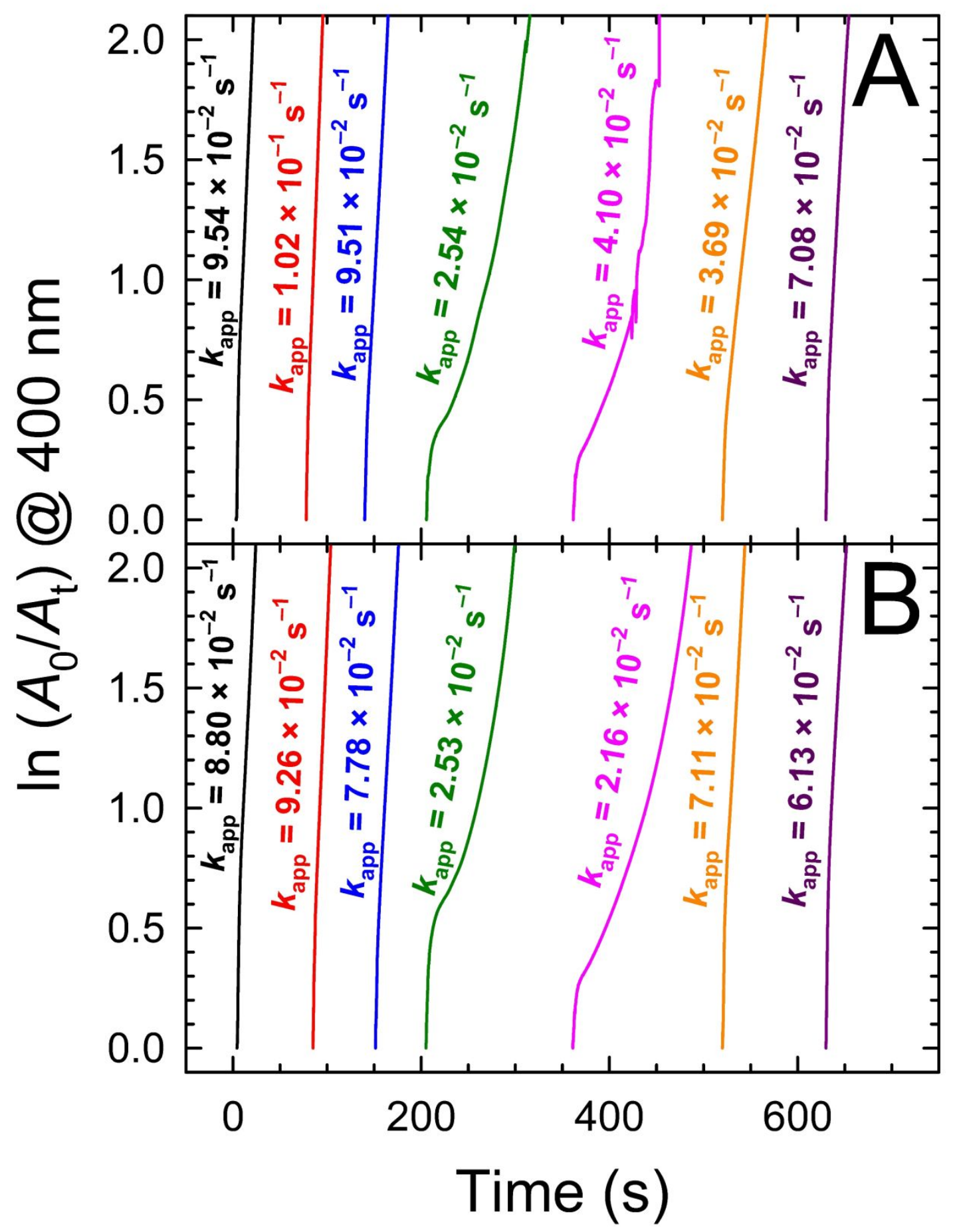

Figure S12. Rate plots showing the change in the apparent rate $\left(k_{\text {app }}\right)$ imposed by recycling A) 10-day-old PINC@AuNPs and B) 2-month-oldPINC@AuNPs for the catalyzed reduction of 4-NP. Both reductions were performed using $0.5 \mathrm{~mol} \%$ Au to 4-NP. Notably, extra $\mathrm{NaBH}_{4}$ was not added until cycles 6 and 7, resulting in a noticeable increase in the apparent rate. Rate retardations of $26 \%$ and $30 \%$ were observed for the 10-day-old and 2-month-old PINC@AuNPs after 7 cycles, respectively, attributed in part to the large increases to both ionic character and product concentration in the latter cycles. 

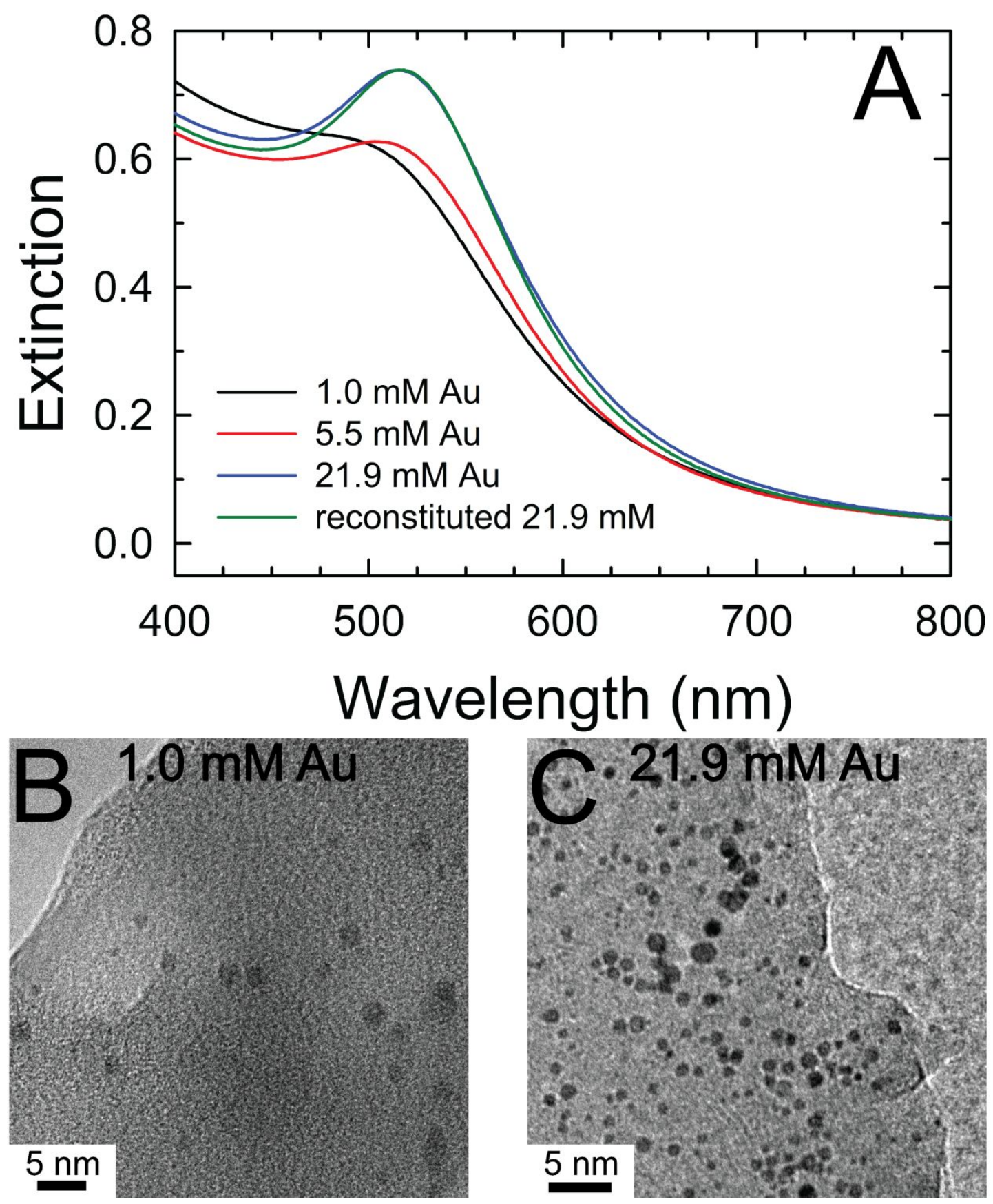

Figure S13. A) UV-vis spectroscopic analysis of PINC@AuNPs synthesized using several Au concentrations (all diluted to $0.25 \mathrm{mM}$ for measurement) as well as the spectrum of a reconstituted aliquot of previously lyophilized 21.9 mM PINC@AuNPs. A red shift in the LSPR is evident as [Au] increases, indicating an increase particle size. Further, the reconstituted PINC@AuNPs solution is nearly identical to its parent solution, indicating that dry storage followed by aqueous dispersion prior to use is an attractive feature of these supported AuNPs. B) and C) TEM images of 1.0 and 21.9 mM PINC@AuNPs, showing $\mathrm{Au}$-free areas in the former image and possible particle aggregation in the latter. The average particle sizes for each sample are below $5 \mathrm{~nm}$. 


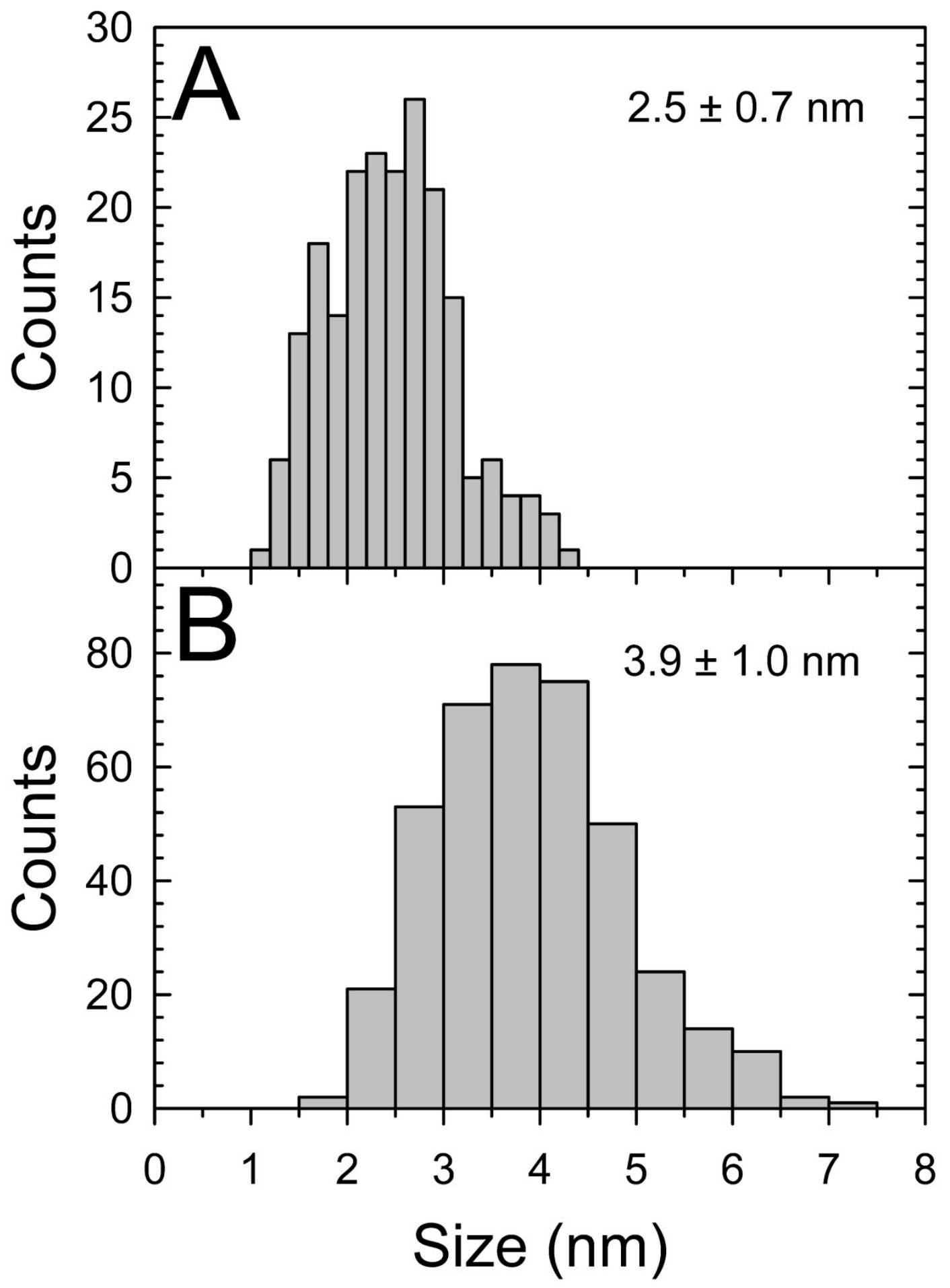

Figure S14. Histograms representing TEM size analysis of A) $1.0 \mathrm{mM}$ PINC@AuNPs and B) $21.9 \mathrm{mM}$ PINC@AuNPs. As observed in the corresponding UV-vis spectral analysis, particles produced at the lower $\mathrm{Au}$ concentration are smaller on average, with no observed particles with diameters larger than $5 \mathrm{~nm}$. Conversely, particles synthesized using a Au concentration of $21.9 \mathrm{mM}$ are about $64 \%$ larger, indicating slight aggregation. Both solutions primarily consist of particles smaller than $5 \mathrm{~nm}$ in diameter, and no particles with diameters larger than $10 \mathrm{~nm}$ were observed. 
1. Wang, Q.; Baker, G. A.; Baker, S. N.; Colon, L. A., Surface Confined lonic Liquid as a Stationary Phase for Hplc. Analyst 2006, 131 (9), 1000-1005.

2. Burkett, S. L.; Press, A.; Mann, S., Synthesis, Characterization, and Reactivity of Layered Inorganic-Organic Nanocomposites Based on 2:1 Trioctahedral Phyllosilicates. Chem. Mater. 1997, 9 (5), 1071-1073.

3. Jeon, Y.; Sung, J.; Seo, C.; Lim, H.; Cheong, H.; Kang, M.; Moon, B.; Ouchi, Y.; Kim, D., Structures of Ionic Liquids with Different Anions Studied by Infrared Vibration Spectroscopy. J. Phys. Chem. B 2008, 112 (15), 4735-4740.

4. Herves, P.; Perez-Lorenzo, M.; Liz-Marzan, L. M.; Dzubiella, J.; Lu, Y.; Ballauff, M., Catalysis by Metallic Nanoparticles in Aqueous Solution: Model Reactions. Chem. Soc. Rev. 2012, 41 (17), 5577-5587.

5. Roy, A. K.; Park, S. Y.; In, I., Mussel-Inspired Synthesis of Boron Nitride Nanosheet-Supported Gold Nanoparticles and Their Application for Catalytic Reduction of 4-Nitrophenol. Nanotechnology 2015, 26 (10), 105601.

6. $\quad$ Gangula, A.; Podila, R.; M, R.; Karanam, L.; Janardhana, C.; Rao, A. M., Catalytic Reduction of 4Nitrophenol Using Biogenic Gold and Silver Nanoparticles Derived from Breynia Rhamnoides. Langmuir 2011, 27 (24), 15268-15274.

7. Qiu, Y.; Ma, Z.; Hu, P., Environmentally Benign Magnetic Chitosan/Fe3o4 Composites as Reductant and Stabilizer for Anchoring Au Nps and Their Catalytic Reduction of 4-Nitrophenol. J. Mater. Chem. A 2014, 2 (33), 13471-13478.

8. Koga, H.; Tokunaga, E.; Hidaka, M.; Umemura, Y.; Saito, T.; Isogai, A.; Kitaoka, T., Topochemical Synthesis and Catalysis of Metal Nanoparticles Exposed on Crystalline Cellulose Nanofibers. Chem. Commun. 2010, 46 (45), 8567-8569.

9. Narayanan, K. B.; Sakthivel, N., Synthesis and Characterization of Nano-Gold Composite Using Cylindrocladium Floridanum and Its Heterogeneous Catalysis in the Degradation of 4-Nitrophenol. J. Hazard. Mater. 2011, 189 (1), 519-525.

10. Ballarin, B.; Cassani, M. C.; Tonelli, D.; Boanini, E.; Albonetti, S.; Blosi, M.; Gazzano, M., Gold Nanoparticle-Containing Membranes from in Situ Reduction of a Gold(lii)-Aminoethylimidazolium Aurate Salt. J. Phys. Chem. C 2010, 114 (21), 9693-9701.

11. Larm, N. E.; Madugula, D.; Lee, M. W.; Baker, G. A., Polyhedral Borane-Capped Coinage Metal Nanoparticles as High-Performing Catalysts for 4-Nitrophenol Reduction. Chem. Commun. 2019, 55 (55), 7990-7993.

12. Deraedt, C.; Salmon, L.; Gatard, S.; Ciganda, R.; Hernandez, R.; Ruiz, J.; Astruc, D., Sodium Borohydride Stabilizes Very Active Gold Nanoparticle Catalysts. Chem. Commun. 2014, 50 (91), 1419414196. 